\title{
Marandu palisade grass management strategies at the beginning of the deferment period and effects on tillering
}

\section{Estratégias para o rebaixamento do capim-marandu no início do período de diferimento e seus efeitos sobre o perfilhamento}

\author{
Manoel Eduardo Rozalino Santos ${ }^{1 *}$; Amanda Bortoleto Ávila²; Angélica Nunes \\ de Carvalho ${ }^{3}$; Gabriel de Oliveira Rocha ${ }^{3}$; Flavia de Oliveira Scarpino van Cleef $f^{4}$; \\ Bruno Nascimento Segatto ${ }^{5}$; Kathleen Alves Vasconcelos ${ }^{5}$; Rayne Souza Pereira ${ }^{5}$
}

\begin{abstract}
Pasture mowing at the beginning of deferment stimulates tillering and can be used in different ways. The aim of this study was to understand how the mowing of Urochloa brizantha cv. Marandu Syn. Brachiaria brizantha cv. Marandu (marandu palisade grass) prior to the deferment period modifies tillering activity and the characteristics of young, mature, and old tillers. Three mowing strategies were evaluated: canopies kept at a height of $15 \mathrm{~cm}$ for five months before deferment $(15 / 15 \mathrm{~cm})$; canopies kept at $30 \mathrm{~cm}(30 / 15 \mathrm{~cm})$ or $45 \mathrm{~cm}(45 / 15 \mathrm{~cm})$ for five months before deferment and posteriorly cut to $15 \mathrm{~cm}$ at the start of the deferment period. The structural characteristics of young, mature, and old tillers of marandu palisade grass were compared only at the end of the deferment period. The tiller appearance rate was greater before $(16.0 \%)$ than during $(6.4 \%)$ the deferment period, but a contrasting response pattern was observed for the tiller mortality rate. The defoliation strategies that resulted in greater numbers of tillers in the canopies were $30 / 15 \mathrm{~cm}\left(2,098\right.$ tillers $\left.\mathrm{m}^{-2}\right)$ and $45 / 15 \mathrm{~cm}(2,160$ tillers $\mathrm{m}^{-2}$ ). The defoliation strategy that generated the greatest percentage of young tillers in the canopy was $45 / 15 \mathrm{~cm}(26.1 \%)$, while the percentage of old tillers was greater in the canopies submitted to the $15 / 15 \mathrm{~cm}(64.1 \%)$ and $30 / 15 \mathrm{~cm}(61.5 \%)$ strategies. Weight and percentage of live stems of mature and old tillers were greater in relation to young tillers. The percentage of live leaves was grater in young tillers $(52.6 \%)$, intermediate in mature tillers $(41.4 \%)$, and lower in old tillers $(21.3 \%)$. Regarding the percentage of dead leaves, the opposite trend was observed, where the percentage was greater in the old than in young tillers. Leaf area was greater in mature tillers $\left(55.3 \mathrm{~cm}^{2}\right)$ than in old tillers $\left(29.2 \mathrm{~cm}^{2}\right)$. Mowing of the marandu palisade grass to $15 \mathrm{~cm}$ at the beginning of the deferment period increases the number of young tillers, which have a more favorable morphological composition than mature and old tillers.
\end{abstract}

Key words: Morphological composition. Dynamics of tillering. Tillers. Urochloa brizantha.

1 Prof. Dr., Universidade Federal de Uberlândia, UFU, Faculdade de Medicina Veterinária, Programa de Pós-Graduação em Ciências Veterinárias, Uberlândia, MG, Brasil. E-mail: manoel.rozalino@ufu.br

2 Zootecnista, UFU, Faculdade de Medicina Veterinária, Uberlândia, MG, Brasil. E-mail: amanda_bortoleto@yahoo.com

3 Zootecnistas, Mestres, Programa dePós-Graduação em Ciências Veterinárias, Uberlândia, MG, Brasil.E-mail: angelicanunescoro@ hotmail.com; gabriel.o.rocha@hotmail.com.br

4 Mestre em Zootecnia, Universidade Estadual Paulista "Júlio de Mesquita Filho", UNESP, Jaboticabal, SP, Brasil. E-mail: flascarpino@hotmail.com

5 Discentes, Curso de Graduação em Zootecnia, UFU, Faculdade de Medicina Veterinária, Uberlândia, MG, Brasil. E-mail: segatto bruno@hotmail.com; kath.alves31@hotmail.com; raynesouza@hotmail.com

* Author for correspondence 


\section{Resumo}

O rebaixamento do pasto no início do diferimento estimula o perfilhamento e pode ser realizado de distintas maneiras. O objetivo deste estudo foi compreender como as formas de rebaixamento da Urochloa brizantha cv. Marandu syn. Brachiaria brizantha cv. Marandu (capim-marandu) no início do diferimento modificam o perfilhamento e as características de perfilhos jovens, maduros e velhos. Três estratégias de rebaixamento foram avaliadas: dossel com $15 \mathrm{~cm}$ cinco meses antes do diferimento $(15 / 15 \mathrm{~cm})$; e dosséis com $30 \mathrm{~cm}(30 / 15 \mathrm{~cm})$ ou $45 \mathrm{~cm}(45 / 15 \mathrm{~cm})$ durante cinco meses e rebaixado para $15 \mathrm{~cm}$ no início do diferimento. Também foram avaliadas as características estruturais de perfilhos jovens, maduros e velhos do capim-marandu ao fim do período de diferimento. A taxa de aparecimento de perfilho foi maior antes $(16,0 \%)$ do que durante $(6,4 \%)$ o período de diferimento, mas um padrão de resposta contrário ocorreu para a taxa de mortalidade de perfilho. As estratégias de desfolhação que resultaram em maior número de perfilho nos dosséis foram as de 30/15 $\mathrm{cm}\left(2.098\right.$ perfilho $\left.\mathrm{m}^{-2}\right)$ e 45/15 $\mathrm{cm}\left(2.160\right.$ perfilho $\left.\mathrm{m}^{-2}\right)$. A estratégia de desfolhação que gerou maior porcentagem de perfilho jovem no dossel foi a de $45 / 15 \mathrm{~cm}(26,1 \%)$, enquanto que a porcentagem de perfilho velho foi maior nos dosséis submetidos às estratégias de $15 / 15 \mathrm{~cm}(64,1 \%)$ e $30 / 15 \mathrm{~cm}(61,5 \%)$. O peso e a percentagem de colmo vivo dos perfilhos maduros e velhos foram maiores em relação ao do perfilho jovem. A porcentagem de folha viva foi maior nos perfilhos jovens $(52,6 \%)$, intermediária no perfilho maduro $(41,4 \%)$ e menor no perfilho velho $(21,3 \%)$. A porcentagem de folha morta apresentou padrão de resposta contrário ao observado para a percentagem de folha viva. A área foliar foi maior no perfilho maduro $\left(55,3 \mathrm{~cm}^{2}\right) \mathrm{e}$ menor no perfilho velho $\left(29,2 \mathrm{~cm}^{2}\right)$. O rebaixamento do capim-marandu de 45 para $15 \mathrm{~cm}$ no início do diferimento aumenta o número de perfilhos jovens no dossel e esses perfilhos possuem melhor composição morfológica, em relação aos maduros e velhos.

Palavras-chave: Área foliar. Composição morfológica. Idade do perfilho. Urochloa brizantha.

\section{Introduction}

Pasture deferment is defined as the selection of a particular area within the pasture to exclude it from grazing. In the southeastern and centralwestern regions of Brazil, this is usually performed in late summer and autumn (SANTOS et al., 2009; TEIXEIRA et al., 2011). This approach guarantees forage mass in periods of scarcity and minimizes the negative effects of seasonal forage production in animal production systems (SANTOS et al., 2009).

In the management of deferred pastures, the forage species is the most important factor, followed by the cultivar. Generally, the use of thin-stemmed plants is recommended, as such species have a high forage accumulation potential during autumn and a low reduction rate of nutritive values during the growth period (SANTOS; BERNARDI, 2005). Species of the genus Brachiaria syn. Urochloa, such as $B$. brizantha cv. Marandu syn. U. brizantha cv. Marandu (Marandu palisade grass), are therefore particularly suited for pasture deferment. Other approaches include cutting at the beginning of the deferment period, which can be achieved through intensive grazing by animals with low nutritional requirements or by mowing. In any case, the objective is to remove old, senescent, and lowquality forage, consequently improving regrowth. Shorter pasture grass allows more light penetration, stimulating the appearance of new vegetative tillers and, consequently, increasing the nutritional value (SOUZA et al., 2012).

Mowing at the beginning of the deferment period can be performed in different ways. The pasture can be cut a few months prior to the beginning of the deferment period, which facilitates the morphological adaptation of the plants to intense and frequent grazing, which may result in a larger number of tillers at the beginning of the deferment period. Alternatively, mowing can be performed immediately prior to the deferment period. In this case, depending on the cutting height, a high percentage of tillers may have their apical meristem 
eliminated, which may increase tiller mortality at the beginning of the deferment period; however, increased light penetration can stimulate the appearance of new tillers (PEREIRA et al., 2011) during the deferment period.

In this context, we aimed to understand the way in which these different approaches to manage marandu palisade grass at the beginning of the deferment period modify the demographic patterns of tillering. In addition, we evaluated the effects of pasture deferment on the characteristics of young, mature, and old tillers.

\section{Material and Methods}

The experiment was conducted from October 2014 to July 2015 in an experimental area at the Capim-Branco Experimental Farm, Federal University of Uberlândia, Uberlândia, MG. The approximate geographical coordinates of the site are $18^{\circ} 30^{\prime}$ 'south latitude and $47^{\circ} 50$ > west longitude of Greenwich; elevation was $776 \mathrm{~m}$ above sea level. The climate of of the area is characterized as Cwa, tropical, with distinct dry and wet seasons (ALVARES et al., 2013).

The experimental area consisted of pastures of Brachiaria brizantha cv. Marandu (Marandu palisade grass), already established and in good condition (with no evidence of degradation). We established 12 experimental plots (experimental units) of $9 \mathrm{~m}^{2}$ each. During the experimental period, the weather conditions were monitored by a meteorological station located approximately $200 \mathrm{~m}$ away from the experimental area (Figure 1).

Figure 1. Rainfall $(\mathrm{mm})$, evapotranspiration $(\mathrm{mm})$, and average, minimum, and maximum temperatures $\left({ }^{\circ} \mathrm{C}\right)$ from October 2014 to July 2015.

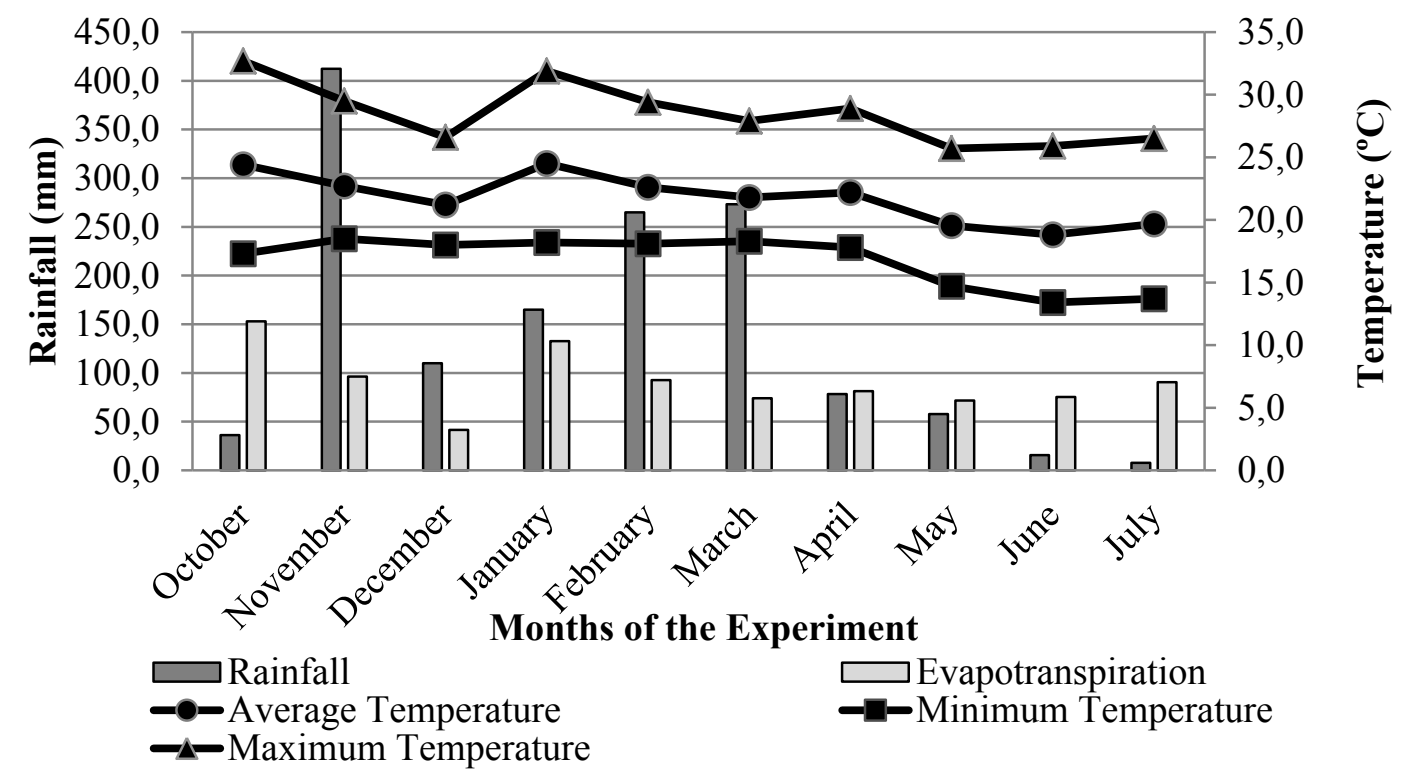

Soil chemical analysis was performed at the beginning of the experimental period in the top soil layer $(0-10 \mathrm{~cm})$, with the following results: $\mathrm{pH}$ in $\mathrm{H}_{2} \mathrm{O}$ : 6.0; P: $5.2\left(\mathrm{Mehlich}^{-1}\right)$ and $\mathrm{K}: 156 \mathrm{mg} \mathrm{dm}^{-3}$;
$\mathrm{Ca}_{2}^{+}: 5.4 ; \mathrm{Mg}^{2+}: 2.0$, and $\mathrm{Al}^{3+}: 0.0 \mathrm{cmol}_{\mathrm{c}} \mathrm{dm}^{-3}(\mathrm{KCl}$ $\left.1 \mathrm{~mol} \mathrm{~L}^{-1}\right)$. Based on these results, fertilization was carried out according to the recommendations of Cantarutti et al. (1999) for a technological 
system of medium level. Therefore, liming and potassium fertilization were not necessary. Nitrogen fertilization was carried out in November 2014 (70 $\mathrm{kg} \mathrm{ha}^{-1}$ of N) and in January 2015 (70 kg ha-1 of N).

Combinations of three plant-mowing strategies at the beginning of the deferment period were evaluated, which corresponded to the primary factor (plot), considering two periods (before and during the deferment period), and the secondary factor (subplot). The mowing strategies were as follows: 1) maintenance of marandu palisade grass at $15 \mathrm{~cm}$ from November 2014, which was five months prior to the beginning of the deferment period $(15 / 15 \mathrm{~cm})$; 2) maintenance of marandu palisade grass at $30 \mathrm{~cm}$ from November 2014; however, at the beginning of the deferment period, the pastures were cut to 15 $\mathrm{cm}(30 / 15 \mathrm{~cm})$; and 3) maintenance of marandu palisade grass at $45 \mathrm{~cm}$ from November; however, at the beginning of the deferment period, the pastures were cut to $15 \mathrm{~cm}(45 / 30 \mathrm{~cm})$. Prior to the deferment period, the plants were maintained at the recommended heights $(15,30$, or $45 \mathrm{~cm})$ through weekly cutting, using pruning shears. After cutting, the excess forage mass was removed.

Prior to the deferment period, we also evaluated the tillering dynamics. For this, in November 2014, two areas of $0.07 \mathrm{~m}^{2}$ per experimental unit were demarcated, using a $30-\mathrm{cm}$ diameter PVC ring fixed to the ground. All the tillers inside the ring were counted and marked; subsequently, every 30 days, new tillers (new generations) were counted. Each tiller generation was identified with plastic-coated wire of different colors and the dead tillers were removed at the end of each counting. After this, we calculated the appearance (TApR), mortality (TMoR), and survival (TSuR) rates of tillers (CARVALHO et al., 2000). In addition, we determined the balance (BAL) between the rates of appearance and mortality of tillers in each month by subtracting these two variables. To calculate the stability index (SI) of the tiller population. We used the equation $\mathrm{SI}=\mathrm{TSuR} \times(1+\mathrm{TApR})(\mathrm{CAMINHA}$ et al., 2010).

In each plot, at the end of the deferment period, the population density of three age categories of tillers was evaluated: young, mature, and old. Young tillers were less than two months old, mature tillers were between two and four months old, and older tillers were older than four months (PAIVA et al., 2011). Identification of the number of total tillers and the percentage of tillers with different ages was performed by the evaluation of the tillering dynamics before the deferment period. At the end of the deferment period, 10 tillers of each age category were collected from each plot and separated into live leaves, live stems, and dead material. The different components were placed in an air-forced ventilation oven at $65^{\circ} \mathrm{C}$ for 72 hours and then weighed. We calculated life leaf weight and total tiller weight as well as the percentages of live leaf, dead leaf, and live stem of the tillers.

To determine the leaf area index, 40 leaf blades were collected from each plot, placed into labeled plastic bags, and taken to the laboratory, where the edges of each leaf blade were cut into a rectangular format. Subsequently, the length and width of each blade were measured in order to estimate the area of each leaf blade segment. The leaf blades were dried in air-forced oven at $65^{\circ} \mathrm{C}$ for 72 hours and weighed. By dividing the area and the weight of the leaf segments, the specific leaf area (SLA, in $\mathrm{cm}^{2}$ $\mathrm{mg}^{-1}$ ) was calculated. For the calculation of the area of each tiller (TA), the following equation was used: TA (mass of live leaf blade of the tiller) x SLA.

For each characteristic, analysis of variance was performed in a randomized complete block design. The characteristics of the tillering dynamics were analyzed in a split-plot design with repeated measures over time, in which the mowing strategies were the plots and the period related to the deferment (before and during) represented the subplot. The structural characteristics of the tillers were also analyzed in a split-plot design, with the mowing strategies representing the plots and the age of the 
tiller (young, mature, and old) representing the subplot. The effects of factor levels were compared by Tukey`s test at a level of significance of up to $5 \%$ of probability of occurrence of type I error.

\section{Results and Discussion}

For all response variables, there was no interaction between the defoliation strategy and the deferment period (Table 1).

Table 1. Characteristics of the tillering dynamics of marandu palisade grass subjected to defoliation strategies before and during the deferment period.

\begin{tabular}{cccccccc}
\hline \multirow{2}{*}{ Characteristic } & \multicolumn{3}{c}{ Defoliation strategy } & \multirow{2}{*}{ SEM } & \multicolumn{2}{c}{ Period regarding the deferment } & \multirow{2}{*}{ SEM } \\
\cline { 2 - 3 } & $15 / 15$ & $30 / 15$ & $45 / 15$ & & Before & During & \\
\hline TApR & $12.4 \mathrm{a}$ & $11.6 \mathrm{a}$ & $15.4 \mathrm{a}$ & 1.0 & $16.0 \mathrm{a}$ & $6.4 \mathrm{~b}$ & 3.4 \\
TMoR & $4.5 \mathrm{a}$ & $4.2 \mathrm{a}$ & $6.5 \mathrm{a}$ & 0.6 & $2.8 \mathrm{~b}$ & $7.4 \mathrm{a}$ & 1.6 \\
BAL & $8.0 \mathrm{a}$ & $7.4 \mathrm{a}$ & $9.0 \mathrm{a}$ & 0.4 & $13.1 \mathrm{a}$ & $-1.0 \mathrm{~b}$ & 5.0 \\
TSuR & $95.5 \mathrm{a}$ & $95.8 \mathrm{a}$ & $93.5 \mathrm{a}$ & 0.6 & $97.2 \mathrm{a}$ & $92.6 \mathrm{a}$ & 1.6 \\
SI & $1.08 \mathrm{a}$ & $1.07 \mathrm{a}$ & $1.08 \mathrm{a}$ & 0.003 & $1.13 \mathrm{a}$ & $0.98 \mathrm{~b}$ & 0.05 \\
\hline
\end{tabular}

SEM: standard error mean; 15/15: maintenance of the canopy at $15 \mathrm{~cm}$ for five months before deferment; 30/15 cm: canopy kept at $30 \mathrm{~cm}$ before and mowed to $15 \mathrm{~cm}$ at the beginning of deferment; $45 / 15 \mathrm{~cm}$ : canopy kept at $45 \mathrm{~cm}$ before and mowed to $15 \mathrm{~cm}$ at the beginning of deferment; TApR: tiller appearance rate ( $\%$ in 30 days); TMoR: tiller mortality rate ( $\%$ in 30 days); BAL: balance between appearance and mortality of tillers ( $\%$ in 30 days); TSuR: tiller survival rate ( $\%$ in 30 days); SI: stability index of the tiller. For each characteristic, means followed by the same letter did not differ significantly $(\mathrm{P}>0.05)$ by Tukey's test.

Prior to the deferment period, the tillering rate was greater than during the deferment period (Table 1), possibly due to climatic conditions more favorable to plant growth, such as rainfall and average and minimum temperatures. The precipitation before the deferment period was $988.6 \mathrm{~mm}$, while during deferment, it was $432.6 \mathrm{~mm}$. Average and minimum temperatures before the deferment period were 23.1 and $18.0^{\circ} \mathrm{C}$, respectively; during the deferment period, we measured 20.4 and $15.6^{\circ} \mathrm{C}$, respectively. Nitrogen fertilization prior to deferment might have stimulated TApR (MARTUSCELLO et al., 2015). However, during the deferment period, no fertilization was performed. In a study on the effects of nitrogen fertilization on pastures of marandu palisade grass managed in continuous stocking, Paiva et al. (2011) observed a positive impact of nitrogen on TApR; according to the authors, N contributed to the rapid renewal of tillers in the pasture, resulting in a population of younger tillers.

On the one hand, in our study, the tiller mortality rate was greater during the deferment period than prior to deferment (Table 1). With adverse weather conditions during deferment, in the autumn and winter months, tiller mortality was higher than tiller appearance, leading to a negative balance between TApR and TMoR during deferment. On the other hand, due to more favorable conditions prior to the deferment period, this balance was positive (Table 1).

During the deferment period, the minimum temperature was below the lower base temperature, which is $18.6^{\circ} \mathrm{C}$ for marandu palisade grass (RODRIGUES, 2004). In this sense, plant growth was impeded. Water restriction also decreases the appearance of tillers as it leads to reduced photosynthesis rates (TAIZ; ZEIGER, 2012). One of the effects of water restriction on forage grass is the loss of leaf area through senescence (CARVALHO et al., 2016), which reduces canopy photosynthesis and, consequently, tillering (SANTOS et al., 2011).

Tiller survival rate (TSuR) did not vary between the periods studied (Table 1); it was expected to be 
greater during the deferment period to compensate the lower current TApR at this time. This compensation contributes to maintain perenniality and, in part, the stability of the tiller population (CARVALHO et al., 2000; SBRISSIA et al., 2010; PORTELA et al., 2011). In addition, the increase in live tillers in winter is a way of conserving resources (nutrients), which is important in dry soil, making it difficult for the plant to absorb nutrients.

The stability index of the tiller population indicates whether the emergence of tillers is sufficient to replace those that are dying (BAHMANI et al., 2003), indicating whether the tiller population is stable (value equal to 1.0), decreasing (value less than 1.0), or increasing (value greater than 1.0). In our study, this index was greater before deferment (Table 1), because at this time, the climate and the nitrogen fertilization favored the appearance of new tillers, which did not occur during deferment.

The defoliation strategies did not influence the characteristics of the tillering dynamics (Table 1). However, it was expected that in the pasture maintained at shorter heights $(15 / 15 \mathrm{~cm})$, tiller appearance and mortality rate would be greater because of the more rapid tiller renewal (SBRISSIA et al., 2010), since more light reaches the base of the plants, favoring tiller (CARVALHO et al., 2000; SBRISSIA; SILVA, 2008). In this sense, Sbrissia et al. (2010), working on pastures of marandu palisade grass maintained at heights of $10,20,30$, and $40 \mathrm{~cm}$ under continuous stocking, verified greater TApR in 10 and $20 \mathrm{~cm}$ high pastures and lower values in the 30 and $40 \mathrm{~cm}$ high pastures.

We observed greater amounts of total tillers in the $30 / 15 \mathrm{~cm}$ and $45 / 15 \mathrm{~cm}$ pastures, compared to the $15 / 15 \mathrm{~cm}$ strategy (Table 2). It is likely that the abrupt cut of theses pastures could have promoted a greater incidence of light at the base of the plants and may have stimulated tillering at the beginning of the deferment period (CARVALHO et al., 2000; SBRISSIA; SILVA, 2008). Most likely, this occurred because the pastures at $30 / 15 \mathrm{~cm}$ and $45 / 15 \mathrm{~cm}$ were taller, which may have resulted in a high concentration of $\mathrm{CO}_{2}$ and an increase in the photosynthetic rate and, therefore, a higher accumulation of reserve compounds (WALTER et al., 2015). These reserves may have been used for the development of basal buds in new tillers. Paiva et al. (2011) also stated that the growth of young tillers can be stimulated by the reserve compounds accumulated in the plant, which increases the forage production of the canopy. Otherwise, it is possible that pastures kept at $15 / 15 \mathrm{~cm}$, because of the lower height and probably lower leaf area index, received less light, resulting in lower photosynthetic rates. This, in turn, did not guarantee the high accumulation of reserve compounds for use in tillering during the deferment period.

Table 2. Total number of tillers and relative participation of young, mature, and old tillers of marandu palisade grass at the end of the deferment period.

\begin{tabular}{lcccc}
\hline \multirow{2}{*}{ Characteristic } & \multicolumn{3}{c}{ Defoliation strategy } & \multirow{2}{*}{ SEM } \\
\cline { 2 - 4 } & $15 / 15 \mathrm{~cm}$ & $30 / 15 \mathrm{~cm}$ & $45 / 15 \mathrm{~cm}$ & 571.9 \\
Total tillers & $1,891 \mathrm{~b}$ & $2,098 \mathrm{a}$ & $2,160 \mathrm{a}$ & 3.2 \\
Young (\%) & $14.6 \mathrm{~b}$ & $15.6 \mathrm{~b}$ & $26.1 \mathrm{a}$ & 1.0 \\
Mature (\%) & $21.3 \mathrm{a}$ & $22.9 \mathrm{a}$ & $25.1 \mathrm{a}$ & 4.1 \\
Old (\%) & $64.1 \mathrm{a}$ & $61.5 \mathrm{a}$ & $48.8 \mathrm{~b}$ & 4 \\
\hline
\end{tabular}

SEM: standard error mean; 15/15: maintenance of the canopy at $15 \mathrm{~cm}$ for five months before deferment; 30/15 cm: canopy kept at $30 \mathrm{~cm}$ before and mowed to $15 \mathrm{~cm}$ at the beginning of the deferment; $45 / 15 \mathrm{~cm}$ : canopy kept at $45 \mathrm{~cm}$ before and mowed to 15 $\mathrm{cm}$ at the beginning of deferment. For each characteristic, means followed by the same letter did not differ significantly $(\mathrm{P}>0.05)$ by Tukey's test. 
The greater number of tillers in the $30 / 15 \mathrm{~cm}$ and $45 / 15 \mathrm{~cm}$ pastures (Table 2) may result in a deferred pasture with a greater volumetric forage density, which can increase the bite mass and have positive consequences on the ingestive behavior of grazing animals (SANTOS et al., 2010). The defoliation strategy that generated the greatest percentage of young tillers was the maintenance of $45 / 15 \mathrm{~cm}$ pastures (Table 2). During mowing, most of the apical meristems of the tillers were eliminated, since $67 \%$ of the height of this pasture was removed. Thus, many old tillers died and, therefore, there was no apical dominance, which may have stimulated the appearance of new tillers (TAIZ; ZEIGER, 2012). It is also possible that this canopy, as previously mentioned, also has a larger stock of reserve compounds, which probably stimulated the development of new tillers. Regarding the canopies managed at $15 / 15$ and $30 / 15 \mathrm{~cm}$ strategies, the removal of the apical meristems was less intense, which may have kept the tillers alive. Then, at the end of the deferment period, most of the tillers were more than four months old. Therefore, the percentage of old tillers was greater in the canopies submitted to $15 / 15 \mathrm{~cm}$ and $30 / 15 \mathrm{~cm}$ strategies than in those at 45/15 cm (Table 2).

In terms of the percentage of mature tillers, there was no difference among the defoliation strategies (Table 2). It can be assumed that pastures at the $45 / 15 \mathrm{~cm}$ strategy provided satisfactory results, since younger tillers have a better morphological composition, a higher nutritional value (SANTOS et al., 2011), and a greater growth rate potential response to management actions (PAIVA et al., 2011).

For all the response variables, there was no interaction between the defoliation strategy and the age of the tiller (Table 3). The percentages of live leaf, live stem, and dead leaf also did not vary among the defoliation strategies evaluated (Table 3).

Table 3. Characteristics of marandu palisade grass tillers submitted to different defoliation strategies after the deferment period.

\begin{tabular}{|c|c|c|c|c|c|c|c|c|}
\hline \multirow{2}{*}{ Characteristic } & \multicolumn{3}{|c|}{ Defoliation strategy } & \multirow{2}{*}{ SEM } & \multicolumn{3}{|c|}{ Tiller } & \multirow{2}{*}{ SEM } \\
\hline & $15 / 15$ & $30 / 15$ & $45 / 15$ & & Young & Mature & Old & \\
\hline Weight (mg) & $569 \mathrm{~b}$ & $683 \mathrm{a}$ & $694 \mathrm{a}$ & 34.8 & $466 \mathrm{~b}$ & $732 \mathrm{a}$ & $748 \mathrm{a}$ & 79.2 \\
\hline Live leaf $(\%)$ & $37.6 \mathrm{a}$ & $37.4 \mathrm{a}$ & $40.4 \mathrm{a}$ & 0.8 & $52.6 \mathrm{a}$ & $41.4 \mathrm{~b}$ & $21.3 \mathrm{c}$ & 7.9 \\
\hline Live stem $(\%)$ & $37.9 \mathrm{a}$ & $42.2 \mathrm{a}$ & $37.3 \mathrm{a}$ & 1.3 & $36.1 \mathrm{~b}$ & $40.2 \mathrm{a}$ & $41.2 \mathrm{a}$ & 1.4 \\
\hline Dead leaf $(\%)$ & $24.4 \mathrm{a}$ & $20.4 \mathrm{a}$ & $22.3 \mathrm{a}$ & 1.0 & $11.3 \mathrm{c}$ & $18.4 \mathrm{~b}$ & $37.4 \mathrm{a}$ & 6.7 \\
\hline Leaf area $\left(\mathrm{cm}^{2}\right)$ & $36.0 \mathrm{~b}$ & $44.6 \mathrm{a}$ & $48.9 \mathrm{a}$ & 3.3 & $45.0 \mathrm{~b}$ & $55.3 \mathrm{a}$ & $29.2 \mathrm{c}$ & 6.6 \\
\hline
\end{tabular}

SEM: standard error mean; 15/15: maintenance of the canopy at $15 \mathrm{~cm}$ for five months before deferment; $30 / 15 \mathrm{~cm}$ : canopy kept at $30 \mathrm{~cm}$ before and mowed to $15 \mathrm{~cm}$ at the beginning of deferment; $45 / 15 \mathrm{~cm}$ : canopy kept at $45 \mathrm{~cm}$ before and mowed to $15 \mathrm{~cm}$ at the beginning of deferment. For each characteristic, means followed by the same letter did not significantly differ $(\mathrm{P}>0.05)$ by Tukey's test.

The tillers of $30 / 15$ and $45 / 15 \mathrm{~cm}$ pastures were heavier than those of the $15 / 15 \mathrm{~cm}$ pasture (Table $3)$. It is possible that after maintaining deferment higher canopy prior to deferment, some cells have multiplied and lengthened during the deferment period, with morphogenetic patterns determined by the previous canopy structure. This may have generated the greatest stem and leaf elongation during deferment, which resulted in a greater tiller weight (Table 3). The effect of seasonal defoliation on canopy growth in the following seasons is due, in part, to the phenotypic plasticity of the forage plant, which is gradual (NELSON, 2000). The heaviest tillers in the $30 / 15 \mathrm{~cm}$ and $45 / 15 \mathrm{~cm}$ pastures (Table 3) may have predisposed these pastures to greater tipping (SANTOS et al., 2016; TEIXEIRA 
et al., 2011), with negative effects on structure and grazing efficiency.

Tillers in the $30 / 15$ and $45 / 15$ pastures also had a larger leaf area compared to the $15 / 15 \mathrm{~cm}$ canopy tillers (Table 3). This might be because the canopies at $30 / 15$ and $45 / 15 \mathrm{~cm}$ had a greater number of young and mature tillers (Table 2), which have a greater percentage of live leaves (Table 3 ) and, consequently, a larger leaf area in contrast to the $15 / 15 \mathrm{~cm}$ canopy, which constituted a greater percentage of old tillers (Table 2), which presented less live leaves and more stems and dead forage than the young tillers (Table 2). The mature and old tillers were heavier than the young tillers (Table 3 ). This can be explained by the fact that mature and old tillers, because they are generally longer (PAIVA et al., 2012), need a more developed supporting organ (stem). As the stem is denser than the leaf, it contributes to the increase of the tiller weight. This argument also explains the greater percentage of live stems in the mature and old tillers compared to the young tillers (Table 3 ).

Regarding the percentage of live leaves, young tillers had a greater value (Table 3 ) as the leaf growth rate was higher. This agrees with the findings of Carvalho et al. (2001), who worked with Panicum maximum cultivars Mombaça and Tanzânia, and Paiva et al. (2011), who studied the Brachiaria brizantha cultivar Marandu, fertilized with nitrogen. The percentage of dead leaves showed a pattern of response contrary to that observed for the percentage of live leaves (Table 3 ).

Leaf area was smaller in old tillers, intermediate in young tillers, and larger in mature tillers (Table 3). Mature tillers had a larger leaf area than young tillers, most likely due to the greater stage of development, characterized by the exposure of a larger number of longer leaves. However, with advanced development, a part of the leaf area of the tiller begins to decrease due to more intense senescence (ALVIM et al., 2010). This process also increases the dead leaf percentage of the old tillers compared to that of the young ones (Table 3).

Based on the results presented in this study, there is strong evidence that the maintenance of the tallest marandu palisade grass, at 30 or $45 \mathrm{~cm}$, and its shortening to $15 \mathrm{~cm}$ at the beginning of the deferment period improves the pasture structure and facilitates the population density of young tillers in the forage canopy (Table 2). These young tillers have a better morphological composition when compared to mature ones (Table 3). The underlying mechanisms of these patterns of tillering responses and structural characteristics of tillers influence pasture structure and animal performance still need to be elucidated. In addition, further studies are needed to determine if the effects demonstrated in this study will occur in grazing situations and other edaphoclimatic conditions.

\section{Conclusions}

The tillering dynamics of the marandu palisade grass is greater prior to the deferment period. Mowing from 45 to $15 \mathrm{~cm}$ at the beginning of the deferment period results in a greater amount of young and total tillers at the end of this period. Young tillers presented a better morphological composition than mature and old tillers.

\section{References}

ALVARES, C. A.; STAPE, J. L.; SENTELHAS, P. C.; GONÇALVES, J. L. M.; SPAROVEK, G. Köppen's climate classification map for Brazil. Meteorologische Zeitschrift, Stuttgart, v. 22, n. 6, p. 711-728, 2013.

ALVIM, K. R. T.; BRITO, C. H.; BRANDÃO, A. M.; GOMES, L. S.; LOPES, M. T. G. Quantificação da área foliar e efeito da desfolha em componentes de produção de milho. Ciência Rural, Santa Maria, v. 40, n. 5, p. 1017-1022, 2010.

BAHMANI, I.; THOM, E. R.; MATTHEW, C.; HOOPER, R. J.; LEMAIRE, G. Tiller dynamics of perennial ryegrass cultivars derived from different New Zealand ecotypes: effects of cultivar, season, nitrogen fertiliser, and irrigation. Australian Journal of Agricultural Research, Melbourne, v. 54, n. 8, p. 803- 
817, 2003.

CAMINHA, F. O.; SILVA, S. C. da; PAIVA, A. J.; PEREIRA, L. E. T.; MESQUITA, P.; GUARDA, V. D. Estabilidade da população de perfilhos de capimmarandu sob lotação contínua e adubação nitrogenada. Pesquisa Agropecuária Brasileira, Brasília, v. 45, n. 2, p. 213-220, 2010.

CANTARUTTI, R. B.; MARTINS, C. E.; CARVALHO, M. M.; FONSECA, D. M.; ARRUDA, M. L.; VILELA, H.; OLIVEIRA, F. T. T. Pastagens. In: RIBEIRO, A. C.; GUIMARÃES, P. T. G.; ALVAREZ, V. V. H. Comissão de fertilidade do solo do Estado de Minas Gerais recomendação para o uso de corretivos e fertilizantes em Minas Gerais. $5^{\text {a }}$ Aproximação. Viçosa, MG: CFSEMG, 1999. p. 332-341.

CARVALHO, C. A. B.; SILVA, S. C.; SBRISSIA, A. F.; PINTO, L. F. M.; CARNEVALLI, R. A.; FAGUNDES, J. L.; PEDREIRA, C. G. S. Demografia do perfilhamento e taxas de acúmulo de matéria seca em capim tifton 85 sob pastejo. Scientia Agricola, Piracicaba, v. 57, n. 4, p. 591-600, 2000.

CARVALHO, D. D.; MATTHEW, C.; HODGSON, J. Effect of aging in tillers of Panicum maximum on leaf elongation rate. In: PROCEEDINGS OF THE INTERNATIONAL GRASSLAND CONGRESS, 2001, São Pedro. Proceedings... São Pedro, 2001. p. 41-42.

CARVALHO, R. M.; SANTOS, M. E. R.; CARVALHO, B. H. R.; CARVALHO, C. R. A.; SILVEIRA, J. P. F.; COSTA, L. K. P. Morphogenesis of marandu palisade grass closer to or farther from cattle feces varies by season. Semina: Ciências Agrárias, Londrina, v. 37, n. 5, p. 3231-3242, 2016.

MARTUSCELLO, J. A.; SILVA, L. P.; CUNHA, D. N. F. V.; BATISTA, A. C. S.; BRAZ, T. G. S.; FERREIRA, P. S. Adubação nitrogenada em capim-massai: morfogênese e produção. Ciência Animal Brasileira, Goiânia, v. 16, n. 1, p. 1-13, 2015.

NELSON, C. J. Shoot morphological plasticity of grasses: leaf growth vs. Tillering. In: LEMAIRE, G.; HODGSON, J.; MORAES, A.; CARVALHO, P. C. F.; NABINGER, C. (Ed.). Grassland ecophysiology and grazing ecology. Wallingford: CAB-International, 2000. p. 101-126.

PAIVA, A. J.; SILVA, S. C.; PEREIRA, L. E. T.; CAMINHA, F. O.; PEREIRA, M. P.; GUARDA, V. D. Morphogenesis on age categories of tillers in marandu palisade grass. Scientia Agricola, Piracicaba, v. 68, n. 6, p. 626-631, 2011.

PAIVA, A. J.; SILVA, S. C.; PEREIRA, L. E. T.; GUARDA, V. D.; PEREIRA, M. P.; CAMINHA, F.
O.; Structural characteristics of tiller age categories of continuously stocked marandu palisade grass swards fertilized with nitrogen. Revista Brasileira de Zootecnia, Viçosa, MG, v. 41, n. 1, p. 24-29, 2012.

PEREIRA, V. V.; FONSECA, D. M.; MARTUSCELLO, J. A.; BRAZ, T. G. S.; SANTOS, M. V.; CECON, P. R. Características morfogênicas e estruturais de capimmombaça em três densidades de cultivo adubado com nitrogênio. Revista Brasileira de Zootecnia, Viçosa, MG, v. 40, n. 12, p. 2681-2689, 2011.

PORTELA, J. N.; PEDREIRA, C. G. S.; BRAGA, G. J. Demografia e densidade de perfilhos de capimbraquiária sob pastejo em lotação intermitente. Pesquisa Agropecuária Brasileira, Brasília, v. 46, n. 3, p. 315-322, 2011.

RODRIGUES, D. C. Produção de forragens de cultivares de Brachiaria brizantha (Hochst. ex A. Rich) Stapf e modelagem de respostas produtivas em função de variáveis climáticas. 2004. Dissertação (Mestrado em Ciência animal e Pastagens) - Escola Superior de Agricultura Luiz de Queiroz, Universidade de São Paulo.

SANTOS, M. E. R.; FONSECA, D. M.; BRAZ, T. G. S.; SILVA, G. P.; GOMES, V. M.; SILVA, S. P. Características morfogênicas, estruturais e acúmulo de forragem em pastos de capim-braquiária de acordo com a localização das fezes. Revista Brasileira de Zootecnia, Viçosa, MG, v. 40, n. 1, p. 31-38, 2011.

SANTOS, M. E. R.; FONSECA, D. M.; EUCLIDES, V. P. B.; JÚNIOR RIBEIRO, J. I.; NASCIMENTO JÚNIOR, D.; MOREIRA, L. M. Produção de bovinos em pastagens de capim-braquiária diferidas. Revista Brasileira de Zootecnia, Viçosa, MG, v. 38, n. 4, p. 635642, 2009.

SANTOS, M. E. R.; FONSECA, D. M.; SILVA, G. P.; PIMENTEL, R. M.; CARVALHO, V. V.; SILVA, S. P. Estrutura do pasto de capim-braquiária com variação de alturas. Revista Brasileira Zootecnia, Viçosa, MG, v. 39, n. 10, p. 2125-2131, 2010.

SANTOS, M. E. R.; FONSECA, D. M.; SOUSA, D. O. C. Seletividade aparente de bovinos em pastos de capim-braquiária sob períodos de diferimento. Arquivo Brasileiro de Medicina Veterinária e Zootecnia, Belo Horizonte, v. 68, n. 6, p. 1655-1663, 2016.

SANTOS, P. M.; BERNARDI, A. C. C. Diferimento do uso de pastagens. In: SIMPÓSIO SOBRE MANEJO DA PASTAGEM, 22., 2005, Piracicaba. Anais... Piracicaba: FEALQ, 2005. p. 95-118.

SBRISSIA, A. F.; SILVA, S. C. da. Compensação tamanho/densidade populacional de perfilhos em pastos de capim-marandu. Revista Brasileira de Zootecnia, 
Viçosa, MG, v. 37, n. 1, p. 35-47, 2008.

SBRISSIA, A. F.; SILVA, S. C. da; SARMENTO, D. O. L.; MOLAN, L. K.; ANDRADE, F. M. E.; GONÇALVES, A. C.; LUPINACCI, A. V. Tillering dynamics in palisadegrass swards continuously stocked by cattle. Plant Ecology, Oxford, v. 206, n. 2, p. 349-359, 2010.

SOUZA, B. M. L.; VILELA, H. H.; SANTOS, A. L.; SANTOS, M. E. R.; NASCIMENTO JÚNIOR, D.; ASSIS, C. Z.; FARIA, B. D.; ROCHA, G. O. Piata palisadegrass deferred in the fall: effects of initial height and nitrogen in the sward structure. Revista Brasileira de Zootecnia, Viçosa, MG, v. 41, n. 5, p. 1134-1139, 2012.
TAIZ, L.; ZEIGER, E. Plant physiology. Tradução de: SANTARÉM, E. R. et al. 3. ed. Porto Alegre: Artmed, 2012. $690 \mathrm{p}$.

TEIXEIRA, F. A.; BONOMO, P.; PIRES, A. J. V.; SILVA, F. F.; ROSA, R. C. C.; NASCIMENTO, P. V. N. Diferimento de pastos de Brachiaria decumbens adubados com nitrogênio no início e no final do período das águas. Revista Brasileira de Zootecnia, Viçosa, MG, v. 40, n. 7, p. 1480-1488, 2011.

WALTER, L. C.; ROSA, H. T.; STRECK, N. A. Mecanismos de aclimatação das plantas à elevada concentração de $\mathrm{CO}_{2}$. Ciência Rural, Santa Maria, v. 45, n. 9, p. 1564-1571, 2015. 